\title{
An Analysis of Idioms in Sumbawanese Songs
}

\author{
Imas Susilawati ${ }^{1}$, Sartika $^{2}$, Solihin ${ }^{3}$ \\ 1,2,3STKIP Paracendekia NW Sumbawa, Nusa Tenggara Barat, Indonesia \\ Email:imassusilawati918@gmail.com, tikaika1692@gmail.com, solihin.mohe@gmail.com
}

Corresponding Author: Solihin

\begin{abstract}
Article Info
Article History

Received: 2021-11-20

Revised: 2021-12-15

Published: 2022-01-03

\section{Abstract}

This research aimed to find out the meanings and types of idioms contained in 18 Sumbawanese songs. The method used in this study was the qualitative descriptive method. Research data were obtained through interview, documentation, and recording. In the analysis, the theory used was Leech theory (1974) to categorize the types of idiom meanings and the researchers focused on two types of meanings namely

Keywords:

Analysis; denotative and connotative meanings. In addition to this theory, the researchers also

Idioms;

Sumbawa song. used Sudaryat's theory (2011) to classify the types of idioms contained in the 18 Sumbawanese songs. Based on the analysis, it was found that there were 18 idioms from 18 songs that were subject to research. Then from 18 idioms, 5 idioms belong to partial idioms and 13 idioms include full idioms.

\begin{tabular}{l}
\hline Artikel Info \\
\hline Sejarah Artikel \\
Diterima: $2021-11-20$ \\
Direvisi: $2021-12-15$ \\
Dipublikasi: $2022-01-03$
\end{tabular}

Abstrak

Penelitian ini bertujuan untuk mengetahui makna dan jenis idiom yang terdapat dalam 18 lagu Sumbawa. Metode yang digunakan dalam penelitian ini adalah metode deskriptif kualitatif. Data penelitian diperoleh melalui wawancara, dokumentasi, dan perekaman. Untuk proses analisa data, teori yang digunakan adalah teori Leech (1974) untuk mengkategorikan jenis-jenis makna idiom dan peneliti memfokuskan pada dua

Kata kunci: Analisis; jenis makna yaitu makna denotatif dan makna konotatif. Selain menggunakan teori Idiom;

Lagu Sumbawa. tersebut, peneliti juga menggunakan teori Sudaryat (2011) untuk mengklasifikasikan jenis-jenis idiom yang terdapat dalam lagu-lagu Sumbawa. Berdasarkan analisis, ditemukan 18 idiom dari 18 lagu yang menjadi subjek penelitian. Kemudian dari 18 idiom, 5 idiom termasuk idiom parsial dan 13 idiom termasuk idiom penuh.
\end{abstract}

\section{INTRODUCTION}

A language is a communication tool that a person uses to communicate and interact with fellow human beings. Virdaus (2020, p. 162), language is a means of communication to convey a wide variety of information, expressions, and feelings to each other, According to Jones (2013 in Az-Zahra, 2018, p. 1), there are five functions of language, indicating that language (1) is expressive, (2) has strength, (3) is pleasant, (4) is dynamic, and (5) interconnected. This suggests that language encompasses human life as a social being as a whole. It is mentioned in Inazar.blogspot.com:

"Expressive function is a language used to express or convey the expressions of the speaker to himself or the public with a specific purpose. This language function is usually used to express emotions, desires, happiness, sadness and the delivery of messages".

In expressing those feelings, it requires a media name as an intermediary and one of them is through songs. According to Virdaus (2020, p. 162 ), songs are compositions of tones or sounds of art in sequences, combinations, and temporal relationships, usually accompanied by musical instruments to produce musical compositions that have unity and continuity (containing rhythm).

Lyrics are part of the song and the two are inseparable. The lyrics of the song itself are a set of words that songwriters use to express or describe their experiences. According to The Great Dictionary of Indonesian language in Fitri (2017, p. 257), lyrics are literary works (poems) that contain an outpouring of personal feelings. In expressing his or her experiences, poets or songwriters play words and languages to create an appeal and distinctiveness to the lyrics of their song, Fitri (2017, p. 256). One of them is to use the idiom, According to Peaty (1983 in Langi, 2016), idioms are part of an inseparable language. Idioms are also expressions, words, or phrases that have figurative meanings that can be understood in terms of the general use of expressions that are separate from literal meanings. Spears (2007, p. 12) in Langi (2016, p. 2 ), says that idioms can be understood as a collection of words or phrases, which when translated will have a word different from the 
meaning of the word itself. Seidle and Mordie, Binkert (2003, p. 164), mention that idioms are a collection of words with different meanings than the meaning of all words. It means that the Idiom is an expression consisting of two or more words whose meaning is out of its true meaning.

Furthermore, idiom also exists in Sumbawanese songs. For example: First, in Yayan's song titled Sanapat Hajat more precisely in the second verse, Yayan uses the phrase sasai sepat. The phrase is an idiom because they have no connection at all to the words of the shaper. The word sasai literally means "Unite" while the word sepat is "one of the names of Sumbawa food made from fish". The idiom meaning of the phrase sasai sepat refers to the word "Invite to marry". So it can be concluded that in the song "The man wants to invite his lover to marry".

Based on the explanation above, the researchhers were interested in analyzing the idioms contained in Sumbawanese songs. Other reasons for conducting this research are: first, the researchhers wanted to know the meanings and types of idioms contained in Sumbawanese songs. Second, due to the lack of use of idioms in everyday life, many Sumbawanese people, especially the young generations, still or even do not understand the meanings of the song they hear or sing. Therefore, the researchers believed it was necessary to conduct this research.

Based on the background above, the problems of this research are;

$\checkmark$ What are the denotative and connotative meanings of idioms found in Sumbawanese songs?

$\checkmark$ What types of idioms are found in Sumbawanese songs?

\section{Idioms}

Idioms are units of language that differ from their basic meanings. Idioms are also called a phrase in the form of a combination of words that form a new meaning, has nothing to do with the word-forming the base. An idiom is an expression or expression in the form of a term or phrase whose meaning cannot be derived from the literal meaning and the arrangement of its parts but has more figurative meaning that can only be known through common use (Silaban \& Mulyadi 2020, p. 352).

Besides, Chaer (2009, p. 74), defines the idiom as a unit of language (it can be a word, phrase, or sentence) whose meaning cannot be "foretold" from the lexical meaning of its elements nor the grammatical meaning of those units. Furthermore, Puspita (2018, p. 132) states that idiomatic expression is an expression that cannot be understood from the literal meaning of the words of it is composed. It can be concluded that idioms form a new meaning which means that they cannot be derived from the literal meaning of its forming elements, in other words, the Idiom cannot be explained from each of its forming words and deviates from its forming elements.

\section{Types of Idiom}

In this research, the researchers used Sudaryat's theory (2011. p. 80) to analyze the types of idioms contained in the lyric of Sumbawa songs. There are two types of idioms according to Sudaryat (2011), namely:

3. Partial idiom

The partial idiom is an idiom whose meaning is still described from one of its constituent elements. In some idioms, one of the elements still has lexical meaning.

4. Full idiom

The full idiom is an idiom whose meaning is completely in no way reflected in its separate elements. In the idiom, the meaning is unified and cannot be interpreted with the meaning of the shaper.

5. Meaning

Meaning is a concept in human thought with referents outside the language that provokes certain reactions and understandings. Meaning can also be interpreted as an abstract concept of human experience. However, the determination of this concept is not done by individuals, but by people who use language in certain regions. With the agreement, a convention arises so as not to interfere with the communication process in everyday life, (Wulandari, 2013). Besides, Aminuddin (2011, p. 50) also suggested that the meaning can be aligned with meaning, ideas, concepts, statements, messages, information, intentions, hunches, content, and thoughts. It can be concluded that meaning is a message conveyed with words, sentences, and symbols in a context.

The theory used is the theory of meaning proposed by Leech (1974); conceptual meaning, connotative meaning, stylistic meaning, affective meaning, reflective meaning, collocative meaning, and thematic meaning. Based on the seven types of meaning above, this research used conceptual or denotative meaning and connotative meaning. 
6. Conceptual Meaning

Conceptual meaning is called denotative or cognitive meaning. It refers to logical, cognitive, or denotative content. For example, a part of the conceptual meaning of "Needle" may be "thin", "sharp" or "instrument". The conceptual meaning is the base for all the other types of meaning.

7. Connotative Meaning

Leech (1974) proposed that connotative meaning refers to the communicative value of an expression based on what it refers to, above and beyond its purely conceptual content. For example, the word Woman has such connotative meanings as babbling, capable of speech, experienced in cookery, frail, prone to tears, skirt or dress wear. Moreover, the word Internet café connotes the meanings of uncleanliness, unpleasant affairs.

8. Song

A song is a set of words, short poems, compositions of music containing vocal parts (lyrics) performed or sung and usually accompanied by chanting music. According to Oxford Dictionary by As Horn (1995 in Puspita, 2018), "song is the poem set to music, intended to be sung". It combines melody and vocals, although the same composers have written instrumental pieces or musical works without words that mimic the quality of a singing voice. As it is mentioned in https://www.wikipedia.org/wiki/song, there are many kinds of songs, those are pop song, rock n roll, rock, and hip hop. In this study, the researchers only focused on one type of song namely Sumbawanese pop songs.

\section{METHODS}

This research used a descriptive qualitative approach because it gained the descriptive data in the form of vocabulary or sentences. Bogdan and Taylor (1975, p. 5), defined qualitative research methods as research procedures that produced descriptive data in the form of written or spoken words from people and observed behaviors. Furthermore, Sukmadinata (2011, p. 73) also explained qualitative descriptive research, namely research that aims to describe and describe existing phenomena, both natural and human engineering, that pay more attention to the characteristics of quality, interconnectedness, between activities. Based on the descrytion above, it can be concluded that qualitative descriptive research is research by describing the observed data clearly and describing the conditions that what they are.

In this research, there were some data sources used by the researchers in collecting data. Those are primary and secondary data sources. The primary data in this study are collected by conducting interviews directly with parties related to the research to be conducted, namely elders or people who better understand the Sumbawa language and videos of Sumbawanese songs on YouTube. Furthermore, the researchers chose 4 informants to be interviewed as the source of data. While secondary data in this study is sourced is Sumbawanese songs lyrics contained idioms meanings, and other sources related to the research. The data collection techniques used in this research were documenttation and interview. The interview technique used was semi-structured interviews. Interview was used to find data from the sources about the meanings in Sumbawanese songs which are considered to contain idioms, The requirements of informants in this study were:

1. Sumbawa native speaker.

2. Male/female.

3. Age 35 to 65 years (not senile).

4. Educated.

5. Healthy physically and spiritually.

The criteria of each respondent had been determined to be qualified as an informant, as per the requirements. According to Mahsun (2005 in Hartina, 2019), that is sane still sharp memory or not senile, honest and know the source of information.

\section{FINDINGS AND DISCUSSION}

A. Findings

In the data description, there were 18 Sumbawanese songs. The data were analyzed based on the theories of Geoffrey Leech (1974) and Sudaryat (2011). Leech's theory of meaning was used to find out the meanings of idioms found in Sumbawanese songs lyric. Then, Sudaryat's theory was applied in order to find out what types of idioms found in the Sumbawanese songs lyric. In this theory, there are two types of idiom; partial and full idioms. The description is as follows:

1. The Meanings of Idioms Found in Sumbawanese Songs

Based on the data obtained from the documentation (Sumbawanese songs lyric) and interviews, the researchers found there are eighteen denotative and connotetive meanings from eighteen songs that 
become the research subject. The idiom could be seen in following the table. They were:

Table 1. Findings the Meaning of Idiom Found in Sumbawanese Songs

\begin{tabular}{|c|c|c|c|c|}
\hline \multirow{2}{*}{ No } & \multirow{2}{*}{$\begin{array}{l}\text { Songs } \\
\text { Title }\end{array}$} & \multirow{2}{*}{ Idioms } & \multicolumn{2}{|l|}{ Meaning } \\
\hline & & & Denotative & Connotative \\
\hline 1 & $\begin{array}{l}\text { Sanapat } \\
\text { Hajat }\end{array}$ & $\begin{array}{l}\text { Sasai } \\
\text { Sepat }\end{array}$ & $\begin{array}{l}\text { Sasai (Unite) } \\
\text { Sepat (one of } \\
\text { Sumbawa typical } \\
\text { food of the area } \\
\text { made from fish) }\end{array}$ & $\begin{array}{l}\text { Invite to } \\
\text { marry }\end{array}$ \\
\hline 2 & $\begin{array}{l}\text { Loam } \\
\text { Rapuen } \\
\text { Katimis }\end{array}$ & $\begin{array}{l}\text { Loam } \\
\text { Rapuen } \\
\text { Katimis }\end{array}$ & $\begin{array}{l}\text { Loam (is one of } \\
\text { the fruits in } \\
\text { Sumbawa) } \\
\text { Rapuen katimis } \\
\text { (is the name of } \\
\text { the loam tree) }\end{array}$ & $\begin{array}{l}\text { someone } \\
\text { who likes to } \\
\text { lie or liars }\end{array}$ \\
\hline 3 & $\begin{array}{l}\text { Jepen } \\
\text { Sapuen }\end{array}$ & $\begin{array}{l}\text { Jepen } \\
\text { sapuen }\end{array}$ & $\begin{array}{l}\text { Jepen } \\
\text { (Cambodian } \\
\text { flowers in } \\
\text { Sumbawa) } \\
\text { Sapuen } \\
\text { (one tree) }\end{array}$ & $\begin{array}{l}\text { A lonely } \\
\text { place or a } \\
\text { symbol of } \\
\text { the dead }\end{array}$ \\
\hline 4 & $\begin{array}{l}\text { Intan } \\
\text { Samoden } \\
g\end{array}$ & $\begin{array}{l}\text { Intan ku } \\
\text { Samoden } \\
g\end{array}$ & $\begin{array}{l}\text { Intan ku (my } \\
\text { gold) } \\
\text { Samodeng } \\
\text { (Grain) }\end{array}$ & Faith \\
\hline 5 & Pakarap & $\begin{array}{l}\text { Tanam } \\
\text { tinum } \\
\text { dadi nas }\end{array}$ & $\begin{array}{l}\text { Tanam tinum } \\
\text { (growing } \\
\text { cucumbers) } \\
\text { Dadi nas } \\
\text { (become nas) }\end{array}$ & $\begin{array}{l}\text { reality is not } \\
\text { in line with } \\
\text { expectations }\end{array}$ \\
\hline 6 & $\begin{array}{l}\text { Rara no } \\
\text { baketong }\end{array}$ & $\begin{array}{l}\text { Basai } \\
\text { puen }\end{array}$ & $\begin{array}{l}\text { Basai (unite) } \\
\text { puen (tree) }\end{array}$ & $\begin{array}{l}\text { hope to get } \\
\text { married }\end{array}$ \\
\hline 7 & $\begin{array}{l}\text { Timang } \\
\text { raasate }\end{array}$ & $\begin{array}{l}\text { Miker } \\
\text { dua } \\
\text { keleno }\end{array}$ & $\begin{array}{l}\text { Miker think } \\
\text { Dua keleno } \\
\text { (both with } \\
\text { shadows) }\end{array}$ & $\begin{array}{l}\text { bearing her } \\
\text { own load }\end{array}$ \\
\hline 8 & $\begin{array}{l}\text { Ate } \\
\text { kalumpa } \\
k\end{array}$ & $\begin{array}{l}\text { Ate } \\
\text { tukalum } \\
\text { pak }\end{array}$ & $\begin{array}{l}\text { Ate "hati" (Heart) } \\
\text { tukalumpak } \\
\text { (upside down or } \\
\text { spilled) }\end{array}$ & $\begin{array}{l}\text { disappointed } \\
\text { heart }\end{array}$ \\
\hline 9 & $\begin{array}{l}\text { Sampang } \\
\text { jangi }\end{array}$ & $\begin{array}{l}\text { Lenang } \\
\text { mata } \\
\text { jangi }\end{array}$ & $\begin{array}{l}\text { Lenang } \\
\text { (Expanse) } \\
\text { Mata (aye) } \\
\text { jangi (destiny) }\end{array}$ & $\begin{array}{l}\text { after } \\
\text { receiving } \\
\text { destiny }\end{array}$ \\
\hline 10 & $\begin{array}{l}\text { Melong } \\
\text { rasate }\end{array}$ & $\begin{array}{l}\text { Tu } \\
\text { barang } \\
\text { kayu }\end{array}$ & $\begin{array}{l}\text { Tu (people) } \\
\text { Barang } \\
\text { (originally) } \\
\text { Kayu (tree) }\end{array}$ & $\begin{array}{l}\text { other people } \\
\text { are not } \\
\text { relatives or } \\
\text { family }\end{array}$ \\
\hline 11 & $\begin{array}{l}\text { Arung } \\
\text { jonga }\end{array}$ & $\begin{array}{l}\text { Bararun } \\
\text { g jonga }\end{array}$ & $\begin{array}{l}\text { Bararung Jonga } \\
\text { (a shelter like a } \\
\text { beruga whose } \\
\text { roof is half) }\end{array}$ & $\begin{array}{l}\text { left to get } \\
\text { married }\end{array}$ \\
\hline 12 & $\begin{array}{l}\text { Kemang } \\
\text { paranga } \\
n\end{array}$ & $\begin{array}{l}\text { Kemang } \\
\text { paranga } \\
n\end{array}$ & $\begin{array}{l}\text { Kemang (flower) } \\
\text { Parangan } \\
\text { (memory) }\end{array}$ & $\begin{array}{l}\text { the only one } \\
\text { missed }\end{array}$ \\
\hline 13 & $\begin{array}{l}\text { Saling } \\
\text { pajele }\end{array}$ & $\begin{array}{l}\text { Tu mate } \\
\text { saling } \\
\text { pajele }\end{array}$ & $\begin{array}{l}\text { Tu mate (we } \\
\text { dead) } \\
\text { Saling pajele } \\
\text { (lean on each } \\
\text { other) }\end{array}$ & $\begin{array}{l}\text { Relying on } \\
\text { each other }\end{array}$ \\
\hline 14 & $\begin{array}{l}\text { Lala } \\
\text { Saudi }\end{array}$ & $\begin{array}{l}\text { Lala } \\
\text { Saudi }\end{array}$ & $\begin{array}{l}\text { Lala } \\
\text { (designations or } \\
\text { calls for noble or } \\
\text { noble } \\
\text { princesses) } \\
\text { Saudi (country's } \\
\text { name) }\end{array}$ & $\begin{array}{l}\text { a woman } \\
\text { who went to } \\
\text { wander }\end{array}$ \\
\hline 15 & $\begin{array}{l}\text { Palit mo } \\
\text { parujak }\end{array}$ & $\begin{array}{l}\text { Palit mo } \\
\text { parujak }\end{array}$ & Palit mo (lick) & $\begin{array}{l}\text { not getting } \\
\text { anything }\end{array}$ \\
\hline
\end{tabular}

\begin{tabular}{|c|c|c|c|c|}
\hline & & & $\begin{array}{l}\text { Parujak (tools } \\
\text { used for } \\
\text { pounding leaves) }\end{array}$ & \\
\hline 16 & $\begin{array}{l}\text { Liser } \\
\text { samada }\end{array}$ & $\begin{array}{l}\text { Ate } \\
\text { kalangke }\end{array}$ & $\begin{array}{l}\text { Ate } \text { (heart) } \\
\text { Kalangke } \\
\text { (confined or } \\
\text { shackled) }\end{array}$ & heart adrift \\
\hline 17 & $\begin{array}{l}\text { Bendran } \\
\text { g Birayat }\end{array}$ & $\begin{array}{l}\text { Renung } \\
\text { aru gili } \\
\text { arap }\end{array}$ & $\begin{array}{l}\text { Renung (randu) } \\
\text { Aru (plants that } \\
\text { are usually } \\
\text { incorporated } \\
\text { into a) } \\
\text { Gili (small } \\
\text { island) } \\
\text { Arap (hope) }\end{array}$ & $\begin{array}{l}\text { the great } \\
\text { hope for a } \\
\text { beloved } \\
\text { woman }\end{array}$ \\
\hline 18 & $\begin{array}{l}\text { Totang } \\
\text { Dana }\end{array}$ & $\begin{array}{l}\text { Kupagal } \\
\text { ang ares } \\
\text { turen }\end{array}$ & $\begin{array}{l}\text { Kupagalang } \\
\text { (pillow) } \\
\text { Ares (current) } \\
\text { Turen (down) }\end{array}$ & $\begin{array}{l}\text { wallowing in } \\
\text { the void of } \\
\text { hope }\end{array}$ \\
\hline
\end{tabular}

In the table, above shows that of the 18 Sumbawanese songs that became the subject of research, one idiom was found in each song. Each expression or idiom has two meanings namely denotative meaning and connotative meaning.

2. Types of Idiom Found in Sumbawanese Songs

Below is the description of the occurrence of the types of idioms found in Sumbawanese songs.

Table 2. The Classification Types of Idioms Found in Sumbawanese Songs

\begin{tabular}{llll}
\hline No & Songs Title & Idioms & $\begin{array}{l}\text { Types of } \\
\text { Idioms }\end{array}$ \\
\hline 1 & Ate Kalumpak & Ate tu kalumpak & Partial idiom \\
\hline 2 & Sampang Jangi & Lenang mata jangi & Partial idiom \\
\hline 3 & Bendrang birayat & Renung aru gili arap & Partial idiom \\
\hline 4 & Liser samada & Ate kalangke & Partial idiom \\
\hline 5 & Sanapat Hajat & Sasai Sepat & Full idiom \\
\hline 6 & $\begin{array}{l}\text { Loam Rapuen } \\
\text { Katimis }\end{array}$ & Loam rapuen katimis & Full idiom \\
\hline 7 & Jepen Sapuen & Jepen sapuen & Full idiom \\
\hline 8 & Intan Samodeng & Intan ku samodeng & Full idiom \\
\hline 9 & Pakarap & $\begin{array}{l}\text { Tanam tinum dadi } \\
\text { nas }\end{array}$ & Full idiom \\
\hline 10 & $\begin{array}{l}\text { Rara No } \\
\text { Baketong }\end{array}$ & Basai puen & Partial idiom \\
\hline 11 & Timang Rasate & Miker dua keleno & Full idiom \\
\hline 12 & Melong Rasate & Tu barang kayu & Full idiom \\
\hline 13 & Arung Jonga & Bararung jonga & Full idiom \\
\hline 14 & $\begin{array}{l}\text { Kemang } \\
\text { Parangan }\end{array}$ & Kemang parangan & Full idiom \\
\hline 15 & Saling Pajele & Tu mate saling pajele & Full idiom \\
\hline 16 & Lala Saudi & Lala Saudi & Full idiom \\
\hline 17 & Palit Parujak & Palit mo parujak & Full idiom \\
\hline 18 & Totang Dana & $\begin{array}{l}\text { Kupagalang ares } \\
\text { turen }\end{array}$ & Full idiom \\
\hline
\end{tabular}

In table 2 above shows the classification of idiom types namely partial idiom and full idiom. From the eighteen songs found 5 partial idioms and 13 full idioms.

\section{B. Discussion}

This section discussed the result of the research that had been discussed in the 
findings. There are two points that would be discussed to answer the problems of study in chapter 1 such as the meaning of idioms and types of idioms found in Sumbawanese songs. It can be seen as follow:

1. The Meanings of Idioms Found in Sumbawanese Songs

Based on the results of research that has been discussed in the previous part, the researchers found the denotative and connotative meaning of idioms in 18 Sumbawanese songs. The researchers marked every data from the lyrics of the song that became an idiom by using the code SL (song lyrics). Here are some examples of idioms found in Sumbawanese songs.

\section{SL.1: loam rapuen katimis}

The phrase loam rapuen katimis is an idiom consisting of the word loam which denotatively means "is one of the fruits in Sumbawa" and rapuen katimis "the name of the loam tree". However, the meaning connotative or meaning that the singer really wants to convey in the song is "someone who likes to lie or liars". The phrase loam rapuen katimis contained in the sixth verse in the song titled Loam Rapuen Katimis is not merely a singer wanting to describe the unique loam fruit because it has a different name of fruit and tree. However, loam rapuen katimis here connotatively or meaning that the singer really wants to convey is "a person who likes to lie or liars".

\section{SL.2: Ada intan ku samodeng}

The phrase intan $\boldsymbol{k} \boldsymbol{u}$ samodeng is an idiom consisting of the word emas $\boldsymbol{k} u$ which denotatively means "my gold" and samodeng means "one". While connotatively or meaning that really want to be conveyed from the phrase intan $k \boldsymbol{u}$ samodeng in this song means "faith". The phrase of intan ku samodeng is found in the first verse in the song titled Intan Samodeng sang by Oby Pamungkas, where this intan ku samodeng song not only tells about a grain of gold but rather the singer wants to convey that when someone later leaves the world, the only thing that accompanies is faith or deeds.

\section{SL.3: Basai puen gama na}

The phrase Basai puen is an idiom consisting of the word basai which denotatively means "united" and the word puen means "tree". While connotatively or meaning that really want to be conveyed from the expression basai puen is "hope to unite or marry". The phrase basai puen is contained in the third verse in the song titled Rara No Baketong sung by Yayan, in his song the singer uses the phrase basai puen to describe someone who has such great hopes to be able to unite or marry his lover.

\section{SL.4: Miker dua keleno}

The phrase miker dua keleno is an idiom consisting of the word miker which denotatively means "to think" and the word dua keleno means "two with shadows". While the meaning connotative or meaning that really wants to be conveyed from the phrase miker dua keleno is "bear the burden of its own". The phrase miker dua keleno is found in the twelfth verse in the song titled Timang Rasate and sung by Sari Rosami. In her song the singer uses the phrase miker dua keleno to describe solitude. Where no one accompanied him in solving problems, in other words she was alone in bearing the burdens and affairs that existed in his life.

\section{SL.5: Santuret Ate tukalumpak}

The phrase ate tukalumpak is an idiom consisting of the word ate which denotatively means "heart" and the word tukalumpak which means "upside down or spilled". While the meaning connotative or meaning that really wants to be conveyed from the expression ate tukalumpak is "disappointed heart". The phrase ate tukalumpak is found in the twelfth verse in the song titled Santuret Ate Kalumpak which is sung by Adekhamesa, in his song the singer uses the phrase ate tukalumpak to describe someone who is feeling disappointed or his heart is broken because he cannot unite with the worshipper. So, the phrase ate tukalumpak containned in the song titled Santuret Ate kalumpak does not merely mean an inverted heart.

\section{SL.6: Aku tu Barang kayu}

The phrase tu barang kayu is an idiom consisting of the word $\boldsymbol{t} \boldsymbol{u}$ or $\boldsymbol{t a u}$ which denotatively means "person", goods means "origin" and kayu means "wood". While the meaning connotative or meaning that 
really wants to be conveyed from the expression tu barang kayu is "other people are not relatives or family". The phrase tu barang kayu is found in verse eighteen in the song titled Melong Rasate sung by Husain. In his song the singer uses the phrase tu barang kayu to describe someone who is nobody expects to be loved by his lover. This is illustrated in the next verse of the song that reads gawe mares mu pendi.

\section{SL.7: Ate kalangke}

The phrase ate kalangke is an idiom consisting of the word ate which denotatively means "heart" and kalangke meaning "confined or shackled". While the meaning connotative or meaning that really wants to be conveyed from the phrase ate kalangke is "the heart that is attached". The phrase ate kalangke is found in the fourteenth verse in the song titled Liser Samada sung by Epun. In his song the singer uses the phrase ate kalangke to describe someone who is in love.

2. Types of Idiom Found in Sumbawanese Songs

a. Partial idiom

The researchers found there were 5 partial idioms from 18 Sumbawanese songs that became the subject of the study. Some of them are as follows:

1. The phrase Basai puen "hope to unite" is a partial idiom. It is categorized as a partial idiom because the idiom basai puen consists of the word basai "united" and puen "tree". While the meaning that really wants to be conveyed is someone who hopes to be united with his lover in the bonds of marriage. The meaning of the phrase basai puen has a meaning that is not in accordance with its meaning as a whole, namely "the hope to be united with his lover in the bonds of marriage". The word basai in the phrase basai puen still has its own lexical meaning or still has the meaning of the constituent element, while the word puen can not be known seen in the overall meaning of "hope to unite". One of the meanings of the forming element can still be known, this causes this idiom to belong to the full idiom.

2. The phrase ate tu kalumpak "disappointed heart" is a partial idiom. It is categorized as a partial idiom because the phrase ate tukalumpak consists of the word ate "heart" and tukalumpak "upside down or spilled". While the meaning that wants to be conveyed is a disappointed heart. The word ate in the phrase ate tukalumpak still has its own lexical meaning or still has the meaning of the forming element, while the word tu kalumpak cannot be known seen in the overall meaning of "disappointed heart". One of the meanings of the forming element can still be known, this causes this idiom to belong to the partial idiom.

3. The phrase ate kalangke "a linked heart" is a partial idiom. It is categorized as a partial idiom because the phrase ate kalangke consists of the word ate "heart" and kalangke "to be exposed or shackled". While the meaning that really wants to be conveyed is the heart that is attached. The meaning of the word ate in the expression ate kalangke still has its own lexical meaning or still has the meaning of the forming element, while the word kalangke cannot be known seen in the overall meaning of "after or when receiving destiny". One of the meanings of the forming element can still be known, this causes this idiom to belong to the partial idiom.

b. Full Idiom

The researchers found there were 13 full idioms from 18 Sumbawanese songs. Some of them are as follows:

1. The phrase loam rapuen katimis "a person who likes to lie or liar" is a full idiom. Categorized as a full idiom because the phrase loam rapuen katimis consists of the word loam "is one of the fruits in Sumbawa" and rapuen katimis "is a tree of loam fruit". While the meaning that really wants to be conveyed is "people who like to lie or liars". The meaning of 
the word loam and rapuen katimis has a different overall meaning from the forming meaning. This causes this idiom to fall into the full idiom.

2. The phrase intan $k u$ samodeng 'faith' is a full idiom. It is categorized as a full idiom because idiom intan ku samodeng consists of the word intan $\boldsymbol{k u}$ "my gold" and samodeng "grain". While the meaning that really wants to be conveyed is faith. The meaning of the word intanku and samodeng does not correspond to its overall meaning of "faith". The meaning is unified and cannot be interpreted with the meaning of the shaper, this causes this idiom to belong to the full idiom.

3. The phrase mikir dua keleno "bear your own burden" is a full idiom. Categorized as a full idiom because the phrase miker dua keleno consists of the word miker "think" and dua keleno "both with shadow". While the meaning that really wants to be conveyed is to bear its own burden. The meaning of the word miker dua and keleno is not in accordance with the meaning as a whole which is "bear its own burden" where the meaning is fused and can not be interpreted with the meaning of the shaper, this causes this idiom to belong to the full idiom.

4. The phrase tu barang kayu "not relatives or family" is a full idiom. It is categorized as a full idiom because the phrase tu barang kayu consists of the word $\boldsymbol{t} \boldsymbol{u}$ "people", barang "origin" and kayu "wood". While the meaning that really wants to be conveyed is that others are not relatives or family. The meaning of he word tu barang and kayu is not in accordance with its meaning as a whole, namely "other people are not relatives or family" where all the forming elements have fused into one unit, so that the meaning that has come from the whole unity.

\section{CONCLUSION}

Based on the analysis in the previous chapter, the answers of two problems of the study were found. Those are as follows: First, of the seven types of meaning that exist, the researchers only focuses on two types of meaning, namely denotative meaning and connotative meaning. Both types of meanings are found in idioms on eighteen Sumbawanese songs. Second, based on analysis, it can be concluded that there are two types of idioms found in Sumbawanese songs. They are partial idiom and full idiom. From the songs that were the subject of research, there were five partial idioms and thirteen full idioms.

\section{REFERENCES}

Az-Zahra, S. H. (2018). Idiom pada Lirik-lirik Lagu Maroon 5: Kajian Semantik. Universitas Padjajaran.

Aminuddin, (2011), Semantik: Pengantar Studi tentang Makna. Bandung: Sinar Baru.

Bogdan, Robert C. and Taylors K.B, (1992). Qualitative Researtch for Education An Introduction to Theory and Metdods. Boston: Ally and Bacon Inc.

Chaer, Abdul. 2009. Pengantar Semantik Bahasa Indonesia. Jakarta: Rineka Cipta.

Fitri, S. (2017, September). Analisa Semiotik Makna Motivasi Lirik Lagu. Jurnal Komunikasi, VII(3), 261.

Hartina, T. (2019). Analisis Penggunaan Idiom Pada Syair Bakelong di Kecamatan Taliwang Kabupaten Sumbawa Barat. Universitas Muhammadiyah Mataram. 126.

Immanuel Silaban $^{1}$ ), M. (2020). Bentuk, Makna, dan Fungsi Idiom dalam Bahasa Batak Toba. Jurnal Education and development Institut Pendidikan Tapanuli Selatan, 8(1), 352-356.

Jenis-jenis lagu. Taken from: ( HYPERLINK "https://www.wikipedia.org/wiki/song" https://www.wikipedia.org/wiki/song_) di akses 24 Desember 2020

Langi, I. S. (2016). Idiom dalam Film The Godfather. Universitas Sam Ratulangi, 1-12.

Leech, Goefrey, (1974). Semantics. Great Britain: Hazel Watson \& Viney Ltd

Puspita, C. (2018, May). The Analysis of Idiomatic Exspression in Mariah Carey's Songs. Majalah Ilmiah Politeknik Mandiri Bina Prestasi, 7(1), 132-140. 
Pengertian fungsi ekspresif. Taken from : (Inazar.blogspot.com) di akses 12 Desember 2020

Sukmadinata, Nana Syaodih. (2011).Metode Penelitian Pendidikan.Bandung: Remaja Rosdakrya.

Seidl, J. and McMordie, W. 1988. English Idiom 5th Edition. England: Oxford University.

Sudaryat, Yayat. 2011. Makna dalam Wacana Prisip-prinsip Semantik dan Pragmatik. Bandung: Yrama
Virdaus, V. V. (2020). Ekspresi Idiomatik dalam Lirik Lagu "Nine Track Mind" Charlie Puth Album 2016. MOTORIC (Media of Teaching Oriented and Children), 4(1), 161-172.

Wulandari, Purwanti. (2013). Aneka Makna dalam Bahasa Indonesia. Yogyakarta: Citra Aj. 